\title{
PROKSEMIKA/SEMIOTIKA RUANG SEBAGAI SEBUAH PENDEKATAN UNTUK PENELITIAN DESAIN INTERIOR
}

Sumartono*

Program Studi Desain Interior, Fakultas Seni Rupa, Institut Seni Indonesia Yogyakarta

\begin{abstract}
Sometimes called a semiotics of space, proxemics becomes more and more popular as a research method in many academic surroundings. Proxemics is a study of how people make a structure of microspace. Although this method is more popular among anthropologists, today it has been applied in other fields of study as well. A field of study which also benefits from this method is interior design. This is caused by the very fact that interior design deals a lot with microspaces. It is important to employ this method in interior design research in Indonesia.
\end{abstract}

Keywords: interior design, proxemics, research method, semiotics of space

Proksemika (proxemics) adalah sebuah istilah yang dipopulerkan oleh antropolog Edward T. Hall lewat dua buku larisnya The Silent Language (Bahasa Diam) dan The Hidden Dimension (Dimensi Tersembunyi). Secara sempit proksemika diartikan sebagai sebuah cara komunikasi nonverbal, sedangkan secara luas proksemika dianggap sebagai semiotika ruang (semiotics of space). Proksemika adalah kajian tentang bagaimana manusia secara tidak sadar membuat struktur ruang mikro-jarak antar manusia dalam melakukan transaksi harian, organisasi ruang pada rumah tinggal dan bangunan-bangunan, dan pada akhirnya tata kota (Hall, 1963: 1003). Hall adalah seorang antropolog dan ketika ia mengkaji proksemika sesungguhnya dia melakukannya tanpa menggunakan kerangka semiotika. Pakar di kalangan semiotikalah yang menganggap kajian dia sebagai bentuk semiotika, yakni semiotika ruang. Dalam hal ini Umberto Eco dan O. Michael Watsonlah yang mula-mula mengkaji proksemika secara eksplisit sebagai salah satu cabang semiotika.

Proksemika sebagai pendekatan dalam penelitian desain interior belum banyak dibicarakan di Indonesia, apalagi diterapkan di lingkungan perguruan tinggi yang memiliki program studi desain interior. Lepas dari kelebihan dan kekurangannya, pendekatan ini perlu terapkan di Indonesia karena menawarkan berbagai manfaat dalam upaya kita memahami transaksi antar manusia dan antar budaya di dalam ruang interior. Karena Indonesia adalah negara yang terdiri dari berbagai macam etnik dan tersusun oleh berbagai macam budaya, maka penelitian dengan pendekatan ini akan menawarkan amat banyak makna bagi kita. Mengingat juga bahwa jumlah penduduk Indonesia sangat besar, maka transaksi harian manusia Indonesia pastilah amat kaya makna.

\section{Kategori-kategori Analisis Proksemika}

Hall membagi tiga kategori deskripsi proksemik yang bisa digunakan sebagai landasan penelitian, yakni kategori 'jarak interpersonal,' kategori 'ruang,' dan kategori ketiga yang berhubungan dengan 'sistem notasi proksemik.' Dalam kaitan dengan kategori jarak interpersonal (dalam penelitiannya, ia menggunakan budaya Amerika Utara), Hall (1966: 116-129) membagi empat kategori jarak, yakni (1) 'jarak intim' (fase dekat: $0 \mathrm{~cm}-15 \mathrm{~cm}$; fase jauh:

\footnotetext{
*Korespondensi penulis dialamatkan ke Program Studi Desain Interior, Fakultas Seni Rupa, Institut Seni Indonesia Yogyakarta, Tel/Fax: +62 274417219 e-mail: tono2maret@yahoo.co.id
} 
$15 \mathrm{~cm}-45 \mathrm{~cm}$ ), (2) 'jarak personal' (fase dekat: $45 \mathrm{~cm}-75 \mathrm{~cm}$; fase jauh: $75 \mathrm{~cm}-120 \mathrm{~cm}$ ), (3) 'jarak sosial' (fase dekat: $120 \mathrm{~cm}-210 \mathrm{~cm}$; fase jauh: $210 \mathrm{~cm}-360 \mathrm{~cm}$ ), (4) 'jarak publik' (fase dekat: $360 \mathrm{~cm}-750 \mathrm{~cm}$; fase jauh: $750 \mathrm{~cm}$ ).

Kategori-kategori yang dirumuskan oleh Hall ini telah mewakili jarak interpersonal yang terkait dengan transaksi harian manusia. Tetapi harus diingat bahwa dimensidimensi yang menyangkut fase dekat dan fase jauh di atas sifatnya adalah relatif. Dengan demikian akan ada banyak variasi dimensi jika menyangkut sebuah negara dengan banyak jumlah etnik dan budaya seperti Indonesia. Hal ini tentu merupakan sebuah tantangan sangat menarik bagi kegiatan-kagiatan penelitian yang akan menggunakan pendekatan ini.

Berdasarkan kebiasaan berbagai budaya memperlakukan konstelasi ruang, Hall membedakan tiga kategori ruang, yakni tetap (fixed), semi-tetap (semi-fixed), atau bervariasi (variable). 'Ruang tetap' adalah ruang yang dibentuk oleh dinding-dinding dan batas-batas teritorial. 'Ruang semi-tetap' adalah ruang yang susunannya dibentuk oleh unsur-unsur yang bisa bergerak seperti korden, layar, partisi, dan susunan furnitur. 'Ruang bervariasi' adalah ruang informal atau dinamik yang terwujud ketika seseorang membuat variasi ciri-ciri ruang atau jarak interpersonal ruang (1966: 103-112). Dalam sebuah negara dengan aneka ragam etnik dan budaya seperti Indonesia, pembahasan tentang kategori ruang ini menjadi sangat menarik. Hal ini disebabkan karena rakyat Indonesia yang jumlahnya lebih dari dua ratus juta itu hidup dalam lingkungan ruang yang sangat beragam, mulai dari ruang sederhana dan sempit di lingkungan suku-suku terasing hingga ruang sangat luas milik keluarga kaya di perkotaan. Berdasarkan kenyataan ini, penelitian tidak boleh hanya difokuskan pada ruang yang bersifat tetap tetapi juga ruang semi tetap serta ruang bervariasi.

Dalam kaitan dengan kategori ketiga yang berhubungan dengan sistem notasi proksemik, Hall merumuskan delapan variabel yang mewakili sistem notasi perilaku proksemik dalam ruang mikro. Delapan variabel tersebut adalah: (1) 'pengidentifikasi postur dan seks' (postural-sex identifiers) (contoh: perempuan, berdiri), (2) 'orientasi sosiofugal-sosiopetal' (contoh: dari muka-kemuka hingga belakang-ke-belakang), (3) 'kode kinestetik' (menggambarkan jarak bagian-bagian tubuh, dari "menggapai" hingga "kontak"), (4) 'kode sentuhan' (dari "membelai dan memegang" hingga "tanpa kontak apapun"), (5) 'kode visual' (melihat, memandang), (6) 'kode termal'/berkaitan dengan panas (tidak peduli apakah panas terdeteksi atau tidak terdeteksi), (7) 'kode olfaksi' (deteksi bau atau nafas), (8) 'kode suara.' (1963: 1006-1014). Penelitian yang berkaitan dengan kategori-kategori ini pernah dilakukan oleh Watson, yakni penelitian tentang perilaku mahasiswa-mahasiswa internasional (termasuk mahasiswa dari Indonesia) yang sedang menuntut ilmu di Amerika Serikat.

\section{Perkembangan Penggunaan Pendekatan Proksemik \\ Meskipun proksemika semakin} sering digunakan sebagai pendekatan untuk penelitian, termasuk penelitian desain interior, bukan berarti sasaran penggunaan pendekatan itu sudah sesuai dengan harapan. Memang, pembahasan tentang proksemika bisa dijumpai di dalam banyak buku, artikel ilmiah, hasil penelitian, dan internet, tetapi lingkup bahasannya umumnya hanya mencakup aspek pengukuran dan paparan objektif, sedangkan aspek fungsi budayanya belum banyak dibahas secara memadai. Dengan kata lain, secara umum pembahasan yang dilakukan oleh para ahli selama ini baru menyentuh wilayah proksetika (proxetics) dan belum ke wilayah proksemika. Hal ini tentu tidak menguntungkan karena semantik dari perilaku proksemik belum banyak dibahas. Bagi para pendukung pendekatan posmodern, aspek pengukuran dan paparan objektif selalu reduksionistik karena apa yang dinamakan makna tidaklah pernah stabil. Justru aspek paparan subjektiflah yang lebih menarik untuk dikaji. Ketika paparan subyektif dari berbagai pihak berkembang subur, di saat itulah akan semakin terlihat bahwa pengukuran objektif adalah reduksionistik.

Sebetulnya upaya untuk meneliti bagaimana manusia secara tidak sadar membuat struktur ruang mikro berbeda (berdasarkan perbedaan latar belakang 
budaya) pernah diteliti oleh $O$. Michael Watson di tahun 1967. Penelitian terhadap 110 mahasiswa dari berbagai negara (beberapa negara Arab; beberapa negara Asia termasuk Indonesia; Pakistan/India; beberapa negara Amerika Latin; beberapa negara Eropa Utara: dan beberapa negara Eropa Selatan) itu berbentuk kajian observatoris sekaligus deskriptif (Watson, 1970: 63-64). Hasil penelitian menunjukkan bahwa perbedaan budaya menghasilkan perbedaan cara melakukan kontak/nonkontak di dalam ruang. Misalnya, sikap tertentu yang oleh mahasiswa dari negara tertentu dianggap sopan, oleh mahasiswa negara lain dianggap tidak sopan. Contoh lain, jarak kontak dekat (dalam bercakapcakap, duduk berdampingan, dan lain-lain) yang dianggap sopan oleh budaya tertentu belum tentu dianggap sopan oleh budaya yang lain. Banyak sekali contoh lain yang bisa ditambahkan berkaitan dengan penelitian Watson tersebut. Meskipun telah menyinggung aspek budaya, penelitian ini masih belum mengungkap makna budaya yang lebih dalam, di luar aspek objektif dan terukur.

Salah satu hal yang dibahas dalam proksemika adalah teritorialitas manusia, termasuk teritorial manusia dalam ruang. Teritorialitas manusia dalam ruang berkaitan erat dengan aspek budaya. Sebuah contoh bentuk khusus teritorialitas manusia dalam ruang adalah preferensi duduk individuindividu dalam kelompok. Dari sudut semiotika ruang, preferensi ini adalah merupakan indeks peran individu-individu tersebut dalam kelompok (Sommer, 1969: 5873; Henley, 1977: 27-42). Lebih jauh lagi hal ini bisa dikaitkan dengan simbol yang terkait dengan peran individu-individu tersebut. Dari sudut pandang budaya, hal ini bisa juga dikaitkan dengan kekuasaan, gender, dan lain-lain.

Kathleen Kitao dan Kenji Kitao telah berjasa menyusun sebuah bibliografi tentang komunikasi nonverbal antar budaya yang memuat daftar buku-buku tentang hal tersebut sejak masa Hall hingga tahun 1990an. Subjek yang dibahas mencakup kronemika (chronemics/semiotika waktu), proksemika (semiotika ruang), ruang dan teritori personal, tampilan fisik dan pakaian, kinesika (kinesics, menyangkut postur dan gestur), komunikasi taktil, ekspresi wajah, kontak mata dan tatapan, parabahasa, perbedaan seks, dan bahasa. Sayangnya buku-buku semacam ini yang terbaru berasal dari tahun 1980-an, seperti terlihat dari buku tulisan Jacques M, Laroche, Stella TingTomey, dan Sheila Ramsey, Tulisan-tulisan terbaru ini juga belum banyak mengupas persoalan budaya secara mendalam.

Sebuah analisis tentang tema yang berkaitan dengan budaya akan dangkal dan tidak menarik jika tanpa disertai argumentasi ketat. Sejumlah peneliti telah menggunakan strategi dekonstruktif untuk menganalisis tema semacam ini. Dengan strategi ini akan ditemukan inkonsistensi-inkonsistensi yang akan memperkaya pengungkapan makna dari tanda-tanda semiotis. Bagi sebagian orang, analisis semacam ini akan memunculkan kesan inkoherensi pemikiran. Tetapi, bagi mereka yang mendukung strategi ini, hal semacam itu memang tidak boleh dihindari karena apa yang dinamakan pemikiran sesungguhnya memang tidak pernah koheren dan apa yang disebut makna tidak pernah stabil. Meskipun dekonstruksi adalah sebuah strategi pemikiran yang sering diikutsertakan dalam analisis semiotik, sesungguhnya, berdasarkan pandangan Derrida, dekonstruksi adalah 'non-teori tentang non-tanda.'

\section{Kegunaan Pendekatan Proksemika}

Penggunaan proksemika sebagai pendekatan dalam penelitian desain interior adalah sangat penting karena persoalan desain interior sangatlah kompleks. Pesatnya pembuatan bangunan beserta interiornya di berbagai kota di Indonesia menyebabkan kompleksitas persoalan ini menjadi lebih tampak. Dengan semakin mekarnya kotakota di Indonesia, semakin mekar pula jumlah penduduk. Jumlah manusia yang terus bertambah ini menyebabkan semakin kompleksnya ruang mikro yang mereka bentuk. Berbagai bangunan yang setelah didesain tidak menemui banyak masalah pada akhirnya menemui banyak masalah karena harus menghadapi pemakai ruang yang jumlahnya semakin banyak. Karena Indonesia adalah sebuah negara multietnik, maka pembentukan ruang mikro menjadi 
tambah kompleks. Hal ini disebabkan karena masing-masing etnik memiliki kebiasaan sendiri dalam menggunakan ruang.

Pendekatan proksemika bisa digunakan untuk meneliti berbagai isu tentang desain interior di Indonesia. Penggunaan pendekatan ini sangat menantang karena, jika didasarkan pada segi fungsi, jenis interior yang bisa dijadikan sebagai objek penelitian sangat banyak jumlahnya. Ini berarti bahwa masalah yang bisa ditangani juga sangat banyak sehingga makna yang dapat diungkap juga tidak terbatas.

Secara umum kota-kota di Indonesia berpenduduk padat. Hal ini membawa dampak pada padatnya manusia yang terlibat dalam berbagai kegiatan di dalam ruang interior. Mungkin timbul asumsi bahwa kepadatan manusia yang terlibat dalam kegiatan di dalam ruang ini tidak bisa dihindari karena penduduk Indonesia memang besar. Lewat penelitian dengan pendekatan proksemika akan terungkap aspek terukur dan aspek budaya. Sejauh ini, sejak penelitian yang dilakukan oleh Hall, aspek terukur lebih banyak mendapatkan perhatian. Oleh karena itu dalam hal ini perlu dilakukan penelitian yang terfokus pada aspek budaya. Lewat proksemika/semiotika ruang yang terfokus pada aspek budaya akan bisa diungkap berbagai makna, misalnya bagaimana ketidakdisiplinan mengikuti urutan kegiatan telah menyebabkan manusia berdesak-desakan dalam melakukan kegiatan (misalnya dalam aktivitas antri). Lewat pembahasan tentang makna sekunder/konotasi mungkin saja akan terungkap bahwa sebagian besar mereka yang terlibat dalam kegiatan tidak merasa salah untuk tidak disiplin karena ketidakdisiplinan merupakan bagian dari budaya Indonesia. Jika dikembalikan pada pembagian kategori jarak interpersonal sebagaimana dikemukakan oleh Hall di depan, maka ketidakdisiplinan tersebut telah mengakibatkan terlanggarnya kategori 'ruang sosial' dan 'ruang publik' oleh 'ruang personal.' Dengan kata lain, penjagaan jarak tubuh antar manusia (terutama antar manusia berlawanan jenis) bisa tidak terkendali.

Pendekatan proksemika, misalnya, bisa digunakan untuk penelitian interior rumah tinggal. Ketidakadilan pembangunan di Indonesia telah mengakibatkan ketidakadilan distribusi ruang interior rumah tinggal. Di satu sisi kita bisa melihat banyak orang yang "kaya" ruang interior (karena rumah mereka berukuran sangat besar), tetapi di sisi lain kita juga melihat lebih banyak lagi orang yang "miskin" ruang interior (karena rumah mereka berukuran sangat kecil, termasuk dalam kategori rumah sangat sederhana, untuk tidak mengatakan rumah tidak layak huni). Dalam kasus ruang-ruang interior pada rumah sangat besar, kita bisa mengungkap makna berkaitan dengan kekuasaan, otoritas, pengaruh, status sosial, eksklusivisme, anti-sosial, dan lain-lain. Dalam kasus ruang-ruang interior pada rumah sangat kecil, kita bisa mengungkap makna berkaitan dengan keterpinggiran, ketakberdayaan sosial, ketergantungan sosial, keterasingan, ketaknyamanan di dalam ruang, dan lain-lain. Pengungkapan makna tanda-tanda yang berkaitan dengan kasus-kasus ini akan lebih kaya dan menarik jika memuat konotasi tanda dan paparan yang didasarkan pada strategi dekonstruktif.

\section{Prosedur Penelitian}

Karena pengukuran objektif menjadi tumpuan utama, penelitian dengan pendekatan proksemik yang dilakukan selama ini cenderung menjadikan observasi dan wawancara sebagai cara utama pengumpulan data. Dengan cara ini data yang dikumpulkan bisa dikuantifikasi dalam bentuk angka-angka untuk menghasilkan kesimpulan yang bersifat umum. Tentu saja kesimpulan yang dihasilkan tidak mampu mengungkap banyak makna yang berkaitan dengan latar belakang budaya orang-orang yang diteliti. Hal ini akan berbeda jika proksemika diperlakukan sebagai semiotika ruang. Lewat semiotika ruang berbagai makna akan bisa diungkap. Semakin banyak orang melakukan penelitian dengan semiotika ruang akan semakin banyak mengungkap makna. Penelitian semacam ini tidak dilakukan secara deduktif atau induktif tetapi abduktif. Dalam penelitian seperti ini hampir tidak mungkin dibuat kesimpulan yang bersifat umum. Sebagian pakar beranggapan bahwa penelitian seperti ini mengandung bahaya overinterpretasi sehingga kadar 
subjektivitasnya tinggi. Tetapi perlu diingat di sini bahwa sejauh ini banyak hasil analisis semiotik yang mempesona banyak orang, meskipun subjektif, karena mengandung kedalaman berpikir, misalnya analisis yang dilakukan oleh Roland Barthes. Analisis semacam inilah yang diharapkan muncul dalam penelitian semiotika ruang.

Proksemika sebagai semiotika ruang tidak menjadikan observasi dan wawancara sebagai cara utama pengumpulan data dan basis analisis. Dalam penelitian objektif, observasi dan wawancara menghasilkan data primer. Dalam penelitian semiotika ruang, data sekunder yang diperoleh dari berbagai sumber tertulis bisa juga dijadikan sebagai basis analisis. Data sekunder menjadi inspirator penting dalam pengungkapan makna konotatif. Sementara itu observasi dan wawancara akan menambah jelas proses analisis.

Proksemika atau 'semiotika ruang' adalah sebuah pendekatan yang sangat menarik mengingat di Indonesia persoalan ruang adalah sangat kompleks dan bermacam-macam. Sayangnya selama ini penelitian dengan pendekatan proksemik hanya mementingkan analisis yang bersifat objektif, padahal analisis objektif bersifat reduksionis. Seharusnya penelitian dengan pendekatan proksemik juga mementingkan analisis aspek budaya. Penelitian desain interior dengan pendekatan proksemik demikian juga, seharusnya tidak hanya berorientasi objektif tetapi juga kultural.

\section{DAFTAR PUSTAKA}

Hall, Edward T. 1963. A System for the Notation of Proxemic Behavior. American Anthropologist, 65.

1966. Hidden Dimension. Garden City: Anchor Books.

Henley, Nancy. 1977. Body Politics. Englewood Cliffs, N.J.: Prentice-Hall.

Sommer. 1969. Personal Space. Englewood Cliffs, N.J.: Prentice-Hall.

Watson, O.Michael. 1970. Proxemic Behavior. The Hague: Mouton. 